
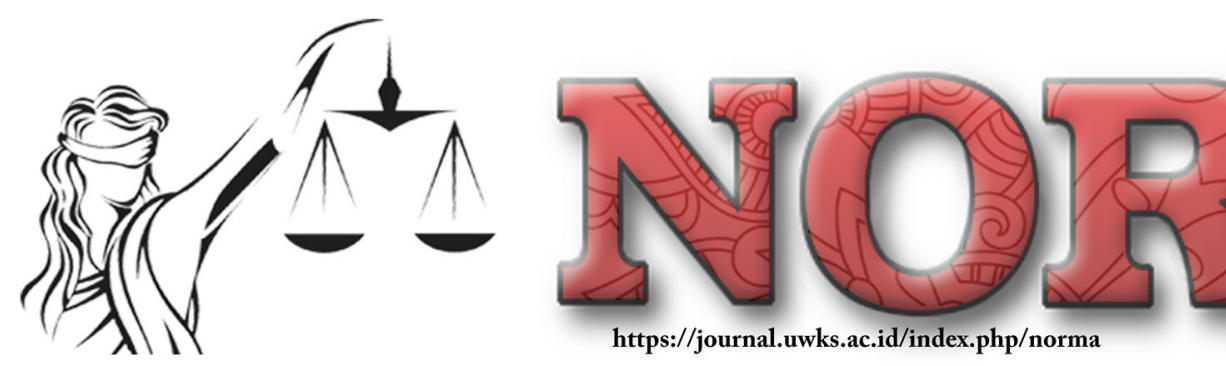

\title{
Legal Consequences for Creditors Caused by Forced Withdrawal of Fiduciary Objects
}

\author{
Ryan Ari Hadinata \\ Legal Observer \\ e-Mail: ryanarihadinata@gmail.com
}

\begin{abstract}
:
The researcher used the title Legal Consequences for Creditors Caused By Forced Withdrawal Of Fiduciary Objects. The formulation of the problems that arise includes, among others: what the creditor can take legal actions if the debtor does not pay the debt when it is due and what are the legal consequences faced by the creditor for the debtor's legal action related to the forced withdrawal of the object of fiduciary security by the creditor, The form of this research method is normative legal research, so in this study, an approach to legislation along with views and doctrines in legal science is analysed which is then analysed against the application of Law to resolve legal issues in this study. From the result the analysis carried out in this study, the researcher states that: as a result of the creditor executing the object of fiduciary security by force when the debtor defaults, it can be subject to criminal sanctions contained in Articles 335, 365, and 368 of the Criminal Code related to using coercion and physical violence and in Article 3 paragraph 1 of the Regulation of the Minister of Finance of the Republic of Indonesia Number 130/PMK.010/2012 which also imposes sanctions on financial institutions that do not register the object of guarantee at the fiduciary guarantee registration office. As for the things that underlie the parties to take legal action, namely: the creditor wants the debtor's obligations to be carried out correctly to pay off his debt. In contrast, the debtor wants to get protection against the forced withdrawal of the object of the guarantee carried out by the creditor.
\end{abstract}

Keywords: Security; Execution; Fiduciary.

Article's History:

Received:

June 3, 2021;

Peer-Reviewed:

June 21, 2021;

Accepted:

July 15, 2021;

Published:

July 30, 2021.

DOI:

10.30742/nlj.v18i2.1588

\section{INTRODUCTION}

Fiduciary guarantees describe the guarantee of trust in the relationship between one person and another so that a sense of confidence in that person grows to further provide their property as collateral to the place they owe. ${ }^{1}$ On the other hand, if the object of the debt guarantee is immovable property, then the collateral must be in the form of a mortgage (currently there is collateral right) where the thing of the security is not given to the creditor but is always in the power of the debtor. ${ }^{2}$ However, even though the debt guarantee qualifies as private property, the creditor may not be

\footnotetext{
${ }^{1}$ Munir Fuady, Jaminan Fidusia (Bandung: Citra Aditya Bakti, 2000), 3.

${ }^{2}$ Ibid.
} 
interested and may be reluctant to submit the proceeds to the creditor regardless of the transfer of the funds. Therefore, when the goods are handed over to the creditor, there is a new guarantee that the object is movable. Still, the power over the thing does not pass from the debtor to the creditor, which is a fiduciary guarantee.

The Fiduciary Guarantee Institution has been known to the public based on the Law of the Republic of Indonesia No. 42 of 1999 concerning Fiduciary Guarantee, Article 1, which states that fiduciary is the transfer of ownership rights to objects based on trust, but what is transferred is still with the owner of the object. ${ }^{3}$

The existence of this fiduciary Law must meet public demands for fiduciary guarantee agreements as a means to support commercial activities and encourage legal certainty for all parties involved. ${ }^{4}$ Law Number 42 of 1999 in Article 1 concerning Fiduciary Guarantees says regulates restrictions on the transfer of fiduciary property rights based on trust, and objects whose ownership rights are transferred remain under the debtor's control.

What is meant by the trust is that something that is a guarantee is still under the debtor's authority; this problem is what the creditor fears when the debtor turns out to be in default. Thus, like other debt guarantee agreements, such as pawns, mortgages, or mortgages, fiduciary agreements symbolize an asesoir agreement. ${ }^{5}$

The form and nature of this guarantee can explain that a great demand or guarantee from the debtor is an essential condition of a credit agreement. In-depth analysis of debtors includes: ${ }^{6}$

1. (Character)

2. (Capacity)

3. (Capital)

4. (Collateral)

5. (Condition of economics).

However, it is necessary to guarantee legal protection for creditors who provide loans by recognizing the needs of the growing business world and providing capital. Then through this Fiduciary Guarantee Law, the Indonesian government seeks to summarize it in the Fiduciary Guarantee Law.

This means that thanks to Law No. 42 of 1999, a registered fiduciary guarantee protects the creditor's position because the creditor has legal contracts to collect the issued credit. Fiduciary arrangements believe that the principle droit de suite is a fiduciary guarantee that obeys wherever the security object is located. ${ }^{7}$

3 Fani Martiawan Kumara Putra, "Pendaftaran Online Jaminan Fidusia Sebagai Suatu Fasilitas Kredit Dengan Potensi Lemahnya Perlindungan Kreditor," Perspektif 24, no. 2 (2019): 95-105.

${ }^{4}$ Gunawan Widjaja, Seri Hukum Bisnis, Jaminan Fidusia (Jakarta: Raja Grafindo Persada, 2001), 5.

${ }_{5}$ Munir Fuady, Jaminan Fidusia, 19.

${ }^{6}$ Suharno, Analisa Kredit (Bandung: Djambatan, 2003), 13.

${ }^{7}$ Gunawan Widjaja, Seri Hukum Bisnis, Jaminan Fidusia, 126. 
This is some basis for building trust: ${ }^{8}$

1. The fiduciary holder is only the holder of the guarantor, not the actual owner;

2. The right of the fiduciary holder to enforce the collateral only exists if the debtor is in default;

3. If the debt has been paid off, the goods deposited must be returned to the original owner;

4. If the income from the auction of fiduciary goods exceeds the amount owed, the remaining payment must be returned to the fiduciary giver.

In addition, for the transfer of rights to be effective in the construction of this fiduciary Law, the following requirements must be met: ${ }^{9}$

1. The agreement is zakelijk.

2. Has the title of transfer of rights.

3. The person who surrenders the property has the right to control the property.

4. Specific delivery methods, namely the constitutum posessorium for materialized movable goods or the method cessie for accounts payable.

Fiduciary needs to be registered because it will be considered weak for this fiduciary Law if it is not registered. In addition to triggering doubts about the Law of fiduciary guarantees, it does not fulfil the element of publicity when not registered, so it isn't easy to control. And things can arise that are not desirable, for example, re-fiduciary without the understanding of creditors. ${ }^{10}$ In addition to the Fiduciary Guarantee Act and other applicable laws, to ensure the security of creditors and debtors, a fiduciary agreement is included in the notarial deed for large loans, where the creditor is calm for the sake of the evidence stated in the notary deed. ${ }^{11}$ Therefore, it is worth to analyze about legal consequences faced by the creditor related to the forced withdrawal of the fiduciary security object.

\section{RESEARCH METHOD}

Research can run well, and the truth must be accounted for with a suitable methodology. Research methods can be understood as moral processes and procedures for solving problems encountered in research. The steps taken should be clear and well defined to avoid over-interpretation. This is a normative legal research with statute approach.

\section{DISCUSSION}

In addition to the trust factor, finance companies that provide credit to debtors must also be based on a written credit agreement, and are generally bound by a

\footnotetext{
${ }^{8}$ Munir Fuady, Jaminan Fidusia, 4.

${ }^{9}$ Ibid.

${ }^{10}$ Ibid

${ }^{11}$ H. Tan Kamelo, Hukum Jaminan Fidusia (Bandung: Alumni, 2014), 25.
} 
notarized contract, thus guaranteeing legal certainty. If the debtor or creditor fails to carry out his obligations, it can be said to have violated the contract. Therefore, although it is a debtor's default in terms of fiduciary guarantees, if the debtor fails to carry out the contents of the agreement or fails to carry out the promised things, the debtor has broken the contract bears all the legal consequences. ${ }^{12}$

UUJF does not use the default but uses breach of contract; the debtor's bankruptcy has critical legal consequences, so it must be regulated in advance in a fiduciary agreement. ${ }^{13}$ If the debtor denies that there was no default during the Execution of the deal, it must be proven by a court hearing.

A debtor who breaks his promise is usually because the debtor cannot fulfil his obligation to pay off debts/credit instalments. Finally, the creditor carries out a confiscation on the object of the fiduciary guarantee and must pay the debtor's interest, fees, and court fees.

In the matter of fiduciary guarantees, the provision of a period of time and a written agreement is critical if there is no agreement at the beginning of the limit until when the debtor must finally fulfil the predetermined achievements, and at that time it can be extended until when without any default or breach of promise.

Default is a situation in which a person fails to perform the obligations required by Law. Therefore, a breach of contract is the result of a failure to enter into a legal agreement. There are four forms of breach of contract, namely: ${ }^{14}$

1. Not doing something that is agreed to be done;

2. Keep promises, but not as promised;

3. Doing something that has been agreed upon but not on time;

4. Doing something according to the agreement is prohibited in the contract.

If it is associated with bad credit, there are three types of behaviour referred to in default, as follows:

1. The debtor is unable to pay off instalments and credit interest.

2. The debtor pays part of the loan instalments and interest;

3. The debtor pays the instalments and interest after the agreed period ends. A written warning is given to a debtor stating that the debtor has fulfilled his obligations at the specified time; if the debtor fails to carry out his duties at that time, the debtor is declared guilty or in default. An express warning can be issued in a formal or informal form. The written notice is formally given by the ruling district court and is called a sommatie. Informal written warnings, such as written letters, telegrams, or delivered to debtors via creditors accompanied by receipts, that is called ingebreke stelling. ${ }^{15}$

${ }^{12}$ Fani Martiawan Kumara Putra, "Utilization Of Debt Collector Services In Debt Secured With Fidusia In Pandemic Period After The Verdict Of The Constitutional Court No. 18/PUU-XVII/2019," Perspektif 25 Nomor 2 (2020).

${ }^{13}$ H. Tan Kamelo, Hukum Jaminan Fidusia, 237.

${ }^{14}$ Ibid.

${ }^{15}$ Abdulkadir Muhammad, Hukum Perdata Indonesia (Bandung: Citra Aditya Bakti, 2000), 204. 
Therefore, if the debtor breaks his promise or defaults and experiences terrible credit, so that in a credit agreement with a deposit guarantee so that in Article 29 of Law Number 42 of 1999 concerning Fiduciary Guarantees, the creditor can carry out executions on objects that are used as fiduciary collateral through implementing the executorial title following the objectives in Article 15 paragraph (2) by the fiduciary recipient or creditor.

In Article 29, paragraph (1) of the Fiduciary Guarantee Law, it is stated that the debtor agreement usually includes a master and final agreement. Therefore, if the parties fail to fulfil the debtor's promise, it will be resolved immediately. ${ }^{16}$

The default here can be in the form of the debtor failing to fulfil its repayment obligations within the due date of debt collection or failing to meet the master agreement and guarantee agreement commitments, even though the debt itself has not matured. If the debtor and creditor are two different people, the debtor's promise will be broken; of course, there is a master agreement, and the creditor's promise violates the guarantee agreement.

If the agreed maturity date between the two parties has passed, then after the due date, a fine can be imposed, and a warning will be given two times a week; the first warning is generally soft if the first warning is ignored, then the creditor will give a second warning that is firmer than before, and when the second warning does not provide a settlement and the debtor is still not responsible, a third warning will be given by giving two options to pay or be sued.

Execution is an ongoing action of all civil procedural laws. Therefore, the legal basis for Execution is an inseparable part of implementing the rules contained in the HIR or RBG. This includes guidelines for applying the rules that refer to the statutory arrangements specified in the HIR and RBG. Related to the Execution of a fiduciary object, then we will look at the execution procedure in Article 15 paragraph (2) of the Fiduciary Law, the Fiduciary Guarantee Certificate, following the objectives in paragraph (1) has the same enforcement power as a court decision that has already been issued, have permanent legal force. ${ }^{17}$

The creditor's right to directly implement the debtor's default is carried out within the time limit allowed by Law, without or before asking for court intervention; this is in the debtor's interest to not pay too many fees to take a long time. However, suppose the debtor does not actively enter into a debt relationship that can be recorded. In that case, the creditor has the right to use the debtor's assets as collateral to demand the Execution of his receivables (right of recovery, right of Execution). ${ }^{18}$

To execute creditors, requesting assistance from parties who have the authority to secure the Execution of fiduciary guarantees. If there is no security from the authorities,

${ }^{16}$ J. Satrio, Hukum Jaminan Hak Jaminan Kebendaan Fidusia (Bandung: Citra Aditya Bakti, 2000), 319.

${ }^{17}$ Ibid, h. 10

${ }^{18}$ Sri Soedewi Maschoen Sofwan, Hukum Perdata: Hukum Benda (Yogyakarta: Liberty, 2000), 31. 
the debtor may conduct anarchic actions beyond the limits. It can run smoothly, safely, orderly, and can be accounted for.

Fiduciary Execution with Executional Title Following the provisions of Article 29 Paragraph 1 letter an of the Fiduciary Law so that the Execution of a fiduciary guarantee object can be carried out based on Grosse fiduciary guarantee certificate or with an executive title, following the provisions in Article 15 Paragraph 2 the fiduciary guarantee certificate has the power of Execution which is similar to a court decision which has permanent legal force.

This fiduciary guarantee certificate has the same enforcement power as decisions from courts that have permanent legal force. Because they have the passion "Demi Keadilan Berdasaekan Ketuhanan yang Maha Esa".

This Fiduciary Guarantee Certificate can be enforced by itself; it does not have to wait for the implementation of a court decision because its power is not different from that of a court that has permanent legal force. Based on the fact that the fiduciary recipient automatically carries out the principal of the collateral that is deposited without waiting for a decision.

Following Article 29 Paragraph 1 letter b in conjunction with Article 15 Paragraph 3 of the Fiduciary Law, through the Law of the Fiduciary Law, the creditor (fiduciary recipient) gives the right or power to sell the collateral which is entrusted with his control (execution parate) to obtain repayment. The debt.

This means that the creditor (fiduciary recipient) does not need to ask the chairman or bailiff of the district court concerned to ask the auction office for help in carrying out the principal of the fiduciary guarantee for public sales or auctions. ${ }^{19}$

But there are stages of executing the auction through the first court procedure by submitting a case application whose purpose is to determine if there is no application letter then the Execution cannot be carried out, a warning which is the initial stage of the execution process by calling the debtor if the debtor does not come then the chairman of the court issues a letter of determination to carry out the confiscation according to the procedures regulated in Article 197 HIR or $208 \mathrm{RBg}$.

As long as the conditions are met, the fiduciary guarantee can also be implemented by selling the fiduciary object in hand. Based on the Fiduciary Law No. 42 of 1999 Article 29, the requirements for a fiduciary to be carried out under the hands are as follows:

1. Following the agreement between the debtor and the creditor who is entrusted with it;

2. If the highest price that benefits both parties is achieved through selling under their hands;

${ }^{19}$ Fani Martiawan Kumara Putra, “Benturan Antara Kreditor Privilege Dengan Kreditor Preferen Pemegang Hipotek Kapal Laut Terkait Adanya Force Majeure," Perspektif 18, no. 1 (2013): 32-45. 
3. The fiduciary giver and/or recipient shall notify the party concerned in writing;

4. Announced it at least two newspapers scattered in the area;

5. The sale is executed one month after receiving written notification.

For matters relating to public auctions, it is regulated that performance guarantee agreements made following applicable regulations must go through public auctions or public auctions. However, the facts prove that this general sale procedure cannot run smoothly and has caused significant losses to creditors. Especially debtors, because of the high general selling costs, which are burdensome for both debtors and creditors, there is a low selling situation.

Therefore, in practice, to obtain a high price, there are often cases where the Execution is carried out through selling at a low price with the highest price agreed upon by the prospective buyer (i.e. debtor and creditor).$^{20}$

Based on the descriptions of the creditor's legal efforts in dealing with debtors who are in default, the authors formulate that there are several ways to take legal action from creditors, namely by ascertaining whether the debtor is in breach of contract or not because the fiduciary guarantee law does not recognize default but is a breach of contract, if the debtor denies that there is no breach of contract in the implementation of the agreement, this matter will be proven in court.

It is hoped that with a persuasive approach, the problem can be resolved without resolving it through legal channels if the compelling approach does not produce results so that the creditor can carry out the Execution of fiduciary collateral objects through various ways, namely carrying out direct executions themselves because in Law No. 42 of 1999 Article 15 concerning guarantees fiduciary, the creditor who registers the fiduciary guarantee to the fiduciary registration office, gets the executive power no different from a court decision.

Fiduciary Eigendom Over Dracht or Transfer of ownership rights based on beliefs based on community needs. People need credit or loans whose collateral is movable objects. Still, movable objects used as collateral remain in the control of the recipient of the facility because the collateral is used to continue their business every day. Given the significant and increasing demand from the business world for the availability of funds to meet the legal requirements for this guarantee, which was issued by Law no. 42 related to fiduciary collateral in 1999. Article 1 of the "Fiduciary Law" stipulates: "fiduciary collateral is collateral for movable goods, including tangible and immovable objects, especially for buildings that cannot be burdened with collateral which is specified in Law No. 4 regarding Mortgage Rights in 1996. The given fiduciary is a dependent who pays certain debts in which the position is offered, prioritizing the fiduciary recipient to other lenders. ${ }^{21}$

\footnotetext{
${ }^{20}$ Sri Soedewi Maschoen Sofwan, Hukum Perdata: Hukum Benda, 36.

${ }^{21}$ Gunawan Widjaja, Seri Hukum Bisnis, Jaminan Fidusia, 3.
} 
The main instruments of fiduciary based on the definition above are:

1. The loan used to pay the debt is a fiduciary guarantee;

2. A certain amount on debt guarantee;

3. The object of a fiduciary grant is a tangible object, movable or a thing with no shape or an object that cannot move, especially a building that cannot be freed-the right of protection where the fiduciary creditor controls the thing used as collateral;

4. Preferred rights or preferential rights aimed at specific lenders with other lenders are fiduciary grants that provide;

5. Ownership rights, collateralized goods are transferred to the lender based on trust, but the object is still in possession of the owner of the goods.

Fiduciary collateral objects are tangible, movable objects or objects with no shape or objects that cannot move, especially buildings that cannot be burdened - the right of protection where the object used as collateral is controlled by the fiduciary creditor. Preferred rights or preferential rights aimed at specific lenders with other lenders are fiduciary grants that provide.

Fiduciary collateral appears from the date the fiduciary guarantee is recorded in the fiduciary register book, the date of birth and coincides with the fiduciary collateral is very meaningful because as a marker and proof of the emergence of special rights and creditor rights as the person in charge of the fiduciary, the lender who receives the fiduciary collateral has a prioritized position concerning with the collateral submitted.

If the priority has not occurred, then the fiduciary collateral has been sold or confiscated by another party, \& the fiduciary collateral cannot be forced. Therefore, the lender loses the priority of the collateral deposited, and the lender only enjoys or shares his rights with other creditors at the same time. At the same time. ${ }^{22}$ The positive perspective of using the person in charge of the deposit is that the procedure is more manageable, flexible, and faster and reduces costs.

The fiduciary collateral guarantee between the recipient of customer financing and the party providing financing as a financing facilitator is inseparable from the customer financing contract. To provide legal firmness to finance companies, it is necessary to register a fiduciary guarantee, for that in 2012 the RI Minister of Finance has set a policy regulation No. 130 of 2012 concerning Registration of Fiduciary Guarantees, which is official for Financing Companies that provide consumer financing related to implementing fiduciary guarantees. Financial service institutions that deviate from their responsibilities in fiduciary registration will receive warnings, freeze business activities or revoked business licenses, etc. What is regulated in Article 3 paragraph 1 of the RI MENKU regulation no. 130/PMK.010/2012

${ }^{22}$ Rudyanti Dorotea Tobing, Hukum Lembaga Pembiayaan, Asas Keadilan Dalam Perjanjian Pembiayaan (Yogyakarta: Laksbang Presindo, 2017), 115. 
Warning sanctions can be given a maximum number of 3 times in writing, valid for 60 days. If the finance company has registered the guarantee before the expiration of the warning period, the Minister of Finance withdraws the warning. If the third warning time is over, but the financial institution does not register for the fiduciary guarantee, the Minister of Finance will freeze the business license.

The sanction for termination of business activity is notified to the financing service business entity in writing no later than 30 days from the date of issuance of the notification of termination of business activity. During the ending of business activities, the financing service business entity registers a fiduciary guarantee, and MENKU withdraws the sanction of terminating business activities. If the termination period of business activities has been completed, but the financing business entity does not register for a fiduciary guarantee, the Minister of Finance will impose a sanction for withdrawing its business license.

Loan recipients can take legal steps to withdraw objects used as collateral in customer financing agreements that require the financing business entity to show a fiduciary guarantee legality letter issued by the fiduciary registration office. Suppose the financing business entity is unable to provide a fiduciary guarantee legality letter. In that case, the loan recipient does not need to give the loan because the financing business entity has no right to seize or take the collateral. Suppose the financing business entity can issue a fiduciary guarantee legality letter. In that case, the next step taken by the loan recipient is to apply a controlling attitude to the re-trading (auction) activity of the collateral object.

The issuance of these rules is for the smooth, safe, orderly and orderly Execution of fiduciary collateral activities and with a sense of responsibility to provide a sense of security for fiduciary creditors, fiduciary debtors and the public from actions that can cause loss and damage to both life and property. Most of the agreements with leasing business entities when taking cars use coercion and physical violence, which violate Articles 335, 365, and 368 of the Criminal Code. In addition, leasing business entities often use a debt collector to confiscate goods by force against bad loans in fiduciary agreements.

Debt collectors often confiscate goods by force on behalf of the leasing business entity. Leasing business entities provide loans to customers who own a vehicle but pay it off through credit. However, the trend in its application is that debt collectors rarely act according to existing norms but violate laws and regulations in the form of threats, intimidation, physical and mental contact in the form of violence. Sometimes the work of debt collectors is not as sporty as what the leasing dealer wants. Sometimes to collect debts in the form of vehicle instalments, they commit acts of violating existing regulations \& harming the borrower who is being collected. 


\section{CLOSING}

\section{Conclusion}

Legal efforts from the creditor due to the debtor not paying the debt when it is due, namely by making persuasive efforts whose aim is to resolve what is at issue between the debtor and creditor through non-legal channels so that the debtor who is in default is willing to pay it off, but if the persuasive approach does not work, the creditor takes action by using debt collector service. Debtor somehow become harmed because of the way of the collaateral object being taken, by using violence. Therefore debtor can report to the police for the act of confiscation by the creditor and can file a lawsuit to the court with the decision of the Constitutional Court No. 18/ PUU-XVII/2019.

\section{Recommendation}

Legal remedies shall be done by filing a lawsuit in court to ensure and request legal assistance based on wanting to execute the object of the debtor's guarantee and the creditor can also execute the object of the fiduciary security directly because, in Article 15 of the fiduciary guarantee law, the fiduciary guarantee certificate as referred to has executorial power, therefore there no need to use the debt collector services.

\section{REFERENCES}

Abdulkadir Muhammad. Hukum Perdata Indonesia. Bandung: Citra Aditya Bakti, 2000.

Gunawan Widjaja. Seri Hukum Bisnis, Jaminan Fidusia. Jakarta: Raja Grafindo Persada, 2001.

H. Tan Kamelo. Hukum Jaminan Fidusia. Bandung: Alumni, 2014.

J. Satrio. Hukum Jaminan Hak Jaminan Kebendaan Fidusia. Bandung: Citra Aditya Bakti, 2000.

Munir Fuady. Jaminan Fidusia. Bandung: Citra Aditya Bakti, 2000.

Putra, Fani Martiawan Kumara. "Benturan Antara Kreditor Privilege Dengan Kreditor Preferen Pemegang Hipotek Kapal Laut Terkait Adanya Force Majeure." Perspektif 18, no. 1 (2013): 32-45.

- - - "Pendaftaran Online Jaminan Fidusia Sebagai Suatu Fasilitas Kredit Dengan Potensi Lemahnya Perlindungan Kreditor." Perspektif 24, no. 2 (2019): 95-105.

- - - "Utilization Of Debt Collector Services In Debt Secured With Fidusia In Pandemic Period After The Verdict Of The Constitutional Court No. 18/PUUXVII/2019." Perspektif 25 Nomor 2 (2020).

Rudyanti Dorotea Tobing. Hukum Lembaga Pembiayaan, Asas Keadilan Dalam Perjanjian Pembiayaan. Yogyakarta: Laksbang Presindo, 2017.

Sri Soedewi Maschoen Sofwan. Hukum Perdata: Hukum Benda. Yogyakarta: Liberty, 2000.

Suharno. Analisa Kredit. Bandung: Djambatan, 2003. 